\title{
PRINCIPAL COMPONENTS OF VARIABLES HYPOTHESISED TO CAUSE PROJECT DELAYS AND COST OVERRUNS IN GHANA
}

\author{
Anthony Q. Q. Aboagye \\ University of Ghana Business School, Box LG 78, Legon, GHANA
}

Tel: 233-244252596;

Email: qaboagye@gmail.com

\begin{abstract}
Many construction projects in developing countries suffer delays because timely completion, within budget, and being of desired quality is dependent on many variables, many of which are not properly managed in these environments. Attempts to get a good grip on reduced (or major) variables or factors to pay attention to have been varied and have yielded varied results. This paper argues that approaches to identifying the number of important variables that affect project delays can be improved further. It uses principal components analysis to identify components of 13 variables hypothesized to affect construction delays and quality in Ghana. A questionnaire was administered to industry stakeholders. The principal axis method was used to extract components which were then subjected to oblique rotation. Five components that explained two-thirds of the variance in the original 13 variables were retained. The study finds that the State of Industry, Infrastructure Availability, and Legal Issues, which proxy industrywide state of affairs in delivering projects load onto Component 1. Consultant Related and Labour Related issues, which speak to the state of human capital load onto Component 2. Project Preparation and Construction Methods load onto Component 3. These variables speak to preparations for specific projects and the methods by which they are undertaken. Change in Government Regulation and Force Majeure, which are exogenous to the industry, load onto Component 4. Finally, Construction Material issues and Equipment Related issues load onto Component 5. We see these variables as inputs to projects.
\end{abstract}

Keywords: construction projects, principal components; Ghana; project delays; eigenvalues; cost overruns

\subsection{Introduction}

A plethora of variables have been reported in the literature as causing and/or determining project delays and cost overruns. Projects delayed beyond scheduled completion dates result typically in cost overruns and often unsatisfactory quality of outputs. Variables identified in the literature to be responsible for delays vary from one study to another and are many. In the circumstance, getting a grip on which variables are important to focus on in order to reduce the chances of project delays is challenging. For example, Assaf and Al-Hejji (2006) identified as many as 73 variables as causes of delays in large projects in Saudi Arabia; Doloi (2009) identified 43 attributes of contractors that impact project delays in a literature search; while Addo (2015) reviewed the literature on causes of construction project delays in Ghana and identified 57 variables.

Many variables affect construction processes and outcomes. The variables are affected by project stakeholders, the state of the national economy, developments within the construction industry, environmental conditions, project location, jurisdiction within which the project is cited, climate, level of industrialization. etc. 
Given the unwieldy number of variables that cause project delays and cost overruns that have been identified in the literature, researchers have tried to get a better grip on the variables by grouping them into what are variously called categories, factors, headings, attributes, etc.

Approaches such as frequency indices, severity indices, relative importance indices and simple ranking have been used by researchers to reduce the variables to more manageable numbers. These approaches are ways of ranking observed variables. They do not result in a reduced number of variables unless an investigator decides on a cut-off number of variables and ignores all others, or an investigator groups these variables and works with the groups. Readers are referred to Assaf and Al-Hejji (2006) for elaboration on these approaches.

Other researchers have used other approaches. For example, Kim et al. (2008) present the knowledge discovery in databases approach, while Doloi (2009) and Doloi et al. (2012) have presented the factor analysis approach. However, knowledge discovery in databases is not widely used, while factor analysis assumes existence of one or more latent variables (which exist but cannot be measured), called factors, that cause observed variables to co-vary to a high extent. Exploratory factor analysis is then undertaken to help identify the number and nature of these latent factors.

This paper argues that approaches to reducing the number of variables can be improved further. It revisits principal components analysis and argues that it will help reduce the number of variables to consider in efforts to reduce project delays in Ghana. Principal components analysis does not make assumptions about causality, which factor analysis does. This paper undertakes principal components analysis on a number of variables that have been identified in the literature. These variables were first screened by knowledgeable persons to reduce their number to a smaller number of variables that these knowledgeable persons believe account for most of the variance in the original variables. The resulting variables were then subjected to principal components analysis to reduce their number further.

The result of this exercise would come in handy in many situations. For example, in focusing energies on a few critical variables to address to minimize project delays; variables to focus on during contract negotiations; and variables to focus on during contract awards. Without doubt, there must be redundancy in the huge number of variables that have appeared in the literature. That is, some variables must be correlated with one another, possibly because they are measuring the same construct and may be eliminated.

It is important to conduct this investigation using Ghanaian data for many reasons. For one thing, in Ghana, foreign exchange to procure sophisticated construction equipment and materials is not readily available. For another, construction owners and clients, including even Government, do not have the financial muscle to readily service their project financial commitments on schedule. Thirdly, personnel involved in construction projects do not benefit much from positive externalities due to limited interaction with experienced foreign construction stakeholders (clients, consultants, contractors, sub-contractors, etc.), the way construction personnel working in places like Saudi Arabia, United Arab Emirates, India, Egypt and Malaysia do. Thus, local peculiarities that result in project delays may abound.

The next section gives some background to project delays in Ghana and discusses strands of the literature that have investigated project delays. It also makes the case for principal component analysis as a worthwhile approach to analyzing causes of project delays. The methodology adopted in implementing principal components analysis is then presented. Findings of this study are then presented, followed by concluding remarks. 


\subsection{Background and Literature}

In the past, Ghana has sought to structure delivery of infrastructure as projects. While some projects have been completed on schedule, at budgeted cost, and have worked as expected, many more have not worked out well. Reports that projects in Ghana are not delivered on schedule and on budget abound. For example, Frimpong et al. (2003) reported that delays and cost overruns occur frequently in construction of groundwater projects in Ghana and developing countries in general. For Ghana, they report that over the period 1970-1999, 33 out of a total of 47 groundwater projects $(70 \%)$ that were completed were delayed; that $75 \%$ of the projects exceeded the original project schedule and cost, and that only $25 \%$ were completed within budget and on time.

Amoatey et al. (2015) documented that the Ghana Social Security and National Insurance Trust (SSNIT) (2013) revealed to them that SSNIT's own investigation showed that 4,700 state housing projects in Ghana had stalled or been completely abandoned for various reasons. Authors further asserted that "in Ghana many projects still continue to delay" and went on to identify causes of delay and their effects on projects and project stakeholders.

Still in Ghana, the building that houses the seat of the presidency that was projected to be built at a cost of USD 30 million (loan from the Indian government) in 2005 was eventually completed in 2008 at USD 135 million, thanks to construction delays and security amendments to the original plan.

Yet another project in Ghana that has suffered delays and cost overruns is the Atuabo Gas Processing Plant in Western Ghana. This project was to carry gas from Ghana's Jubilee Oilfield to gas powered plants in Eastern Ghana. Daily Graphic (2013) reported "It has consistently missed completion deadlines". The hold-up was attributed to delays in disbursements of a USD 3 billion loan from the China Development Bank.

\subsection{Causes of project delays, poor quality and cost overruns}

Across Africa, PricewaterhouseCoopers (2017) reports that in a survey of key players in the infrastructure sector across East, West and Southern Africa, 47\% of respondents indicated that recent projects they were involved in suffered delays of more than six months. The surveyed water, transport and logistics, energy (power and oil \& gas), mining, social infrastructure, telecommunications and real estate sectors. Their survey says the common reasons given for delays were inadequate pre-engineering, weak project management, internal procurement issues involving staff and processes, weak governance, poor planning, lack of visibility, deficient resource planning, unrealistic expectations on timing and scope change. The classified these as internal problems.

PricewaterhouseCoopers (2017) also reports that capital rationing, delays in the release of funds, and failure to provide promised and approved funds account for project delays. They also reported that Government related variables which cause delays take the form of regulatory and legal requirements, delayed approvals and changes in policy. They report that supply chain issues also cause delays.

Other factors that cause project delays have been identified. Assaf and Al-Hejji (2006) reduced their 73 variables that cause delays and cost overruns to nine 'groups'. Doloi (2009) grouped their 43 attributes under 10 broad 'headings'. Addo (2015) categorised his original list 
of 57 variables to eight 'groups'. Amoatey et al. (2015) on their part, reduced 37 variables to 10 'groups'.

There are other studies. For example, Chileshe and Yirenkyi-Fianko (2011) identified 10 'broad sources of risk' in the literature. Doloi et al. (2012) reduced an original list to six 'attributes'. Odeh and Battaineh (2002) categorized 28 variables into 8 major 'groups' and McCord et al. (2015) reduced 75 variables to 10 'groups'. A summary of the content of seven groupings is reported in Table 1.

\subsection{Approaches to investigating importance of different causes of project delays}

A number of approaches have been adopted in the literature to reduce long lists of variables said to be responsible for project delays and/or cost overruns to more manageable 'groups'. Many researchers (for example, Chan and Kumaraswamy, 1997) argue that simple measures of central tendency of individual variables are not suitable measures for assessing overall rankings of causes of project delays because they do not reflect relationships between variables.

Moving beyond simple measures of central tendency, Asaff and Al-Hejji (2006) and many others used frequency index, severity index, relative importance index to rank variables that cause delays. Broadly, the variables that cause project delays are ranked by respondents to a questionnaire. These responses are then analysed for their frequency in causing delays, the severity of delays that they cause and their relative importance (how critical) in causing delays. When interest centres on the association between the rankings of two sets of respondents to a questionnaire of variables that cause project delays, the spearman's rank correlation coefficient is often used.

Doloi et al. (2012) employed factor analysis technique to conclude that the most critical factors responsible for construction delays in India at the time of their study were lack of commitment; inefficient site management; poor site coordination; improper planning; lack of clarity in project scope; lack of communication; and substandard contract as variables affecting project delays in India. 
Table 1: Causes of project delays in the literature - Some identified groupings

\begin{tabular}{|c|c|c|c|c|c|c|c|}
\hline & $\begin{array}{l}\text { Asaff and El- } \\
\text { Hejji (2006) }\end{array}$ & $\begin{array}{l}\text { Amoatey et } \\
\text { al. (2015) }\end{array}$ & Addo (2015) & $\begin{array}{l}\text { Frimpong et } \\
\text { al. }(2003)\end{array}$ & $\begin{array}{l}\text { Chileshe and } \\
\text { Yerenkyi- } \\
\text { Fianko } \\
(2011)\end{array}$ & PWC (2017) & $\begin{array}{l}\text { Doloi et al. } \\
(2012)\end{array}$ \\
\hline 1. & Project related & Financial & $\begin{array}{l}\text { Material } \\
\text { Related }\end{array}$ & $\begin{array}{l}\text { monthly } \\
\text { payment } \\
\text { difficulties }\end{array}$ & Government & $\begin{array}{l}\text { involving new } \\
\text { technologies }\end{array}$ & Project related \\
\hline 2 & Owner related & Resource & Labour Related & $\begin{array}{l}\text { poor contract } \\
\text { management }\end{array}$ & Economic & $\begin{array}{l}\text { on substantial } \\
\text { funding }\end{array}$ & Site related \\
\hline 3 & $\begin{array}{l}\text { Contractor } \\
\text { related }\end{array}$ & Technical & $\begin{array}{l}\text { Equipment } \\
\text { Related }\end{array}$ & $\begin{array}{l}\text { poor material } \\
\text { procurement }\end{array}$ & Technical & Materials & Process related \\
\hline 4 & $\begin{array}{l}\text { Consultant } \\
\text { related }\end{array}$ & Economic & $\begin{array}{l}\text { Finance } \\
\text { Related }\end{array}$ & $\begin{array}{l}\text { poor technical } \\
\text { performances }\end{array}$ & Legal & $\begin{array}{l}\text { regulatory and } \\
\text { environmental } \\
\text { approvals }\end{array}$ & Human related \\
\hline 5 & Design related & Environmental & $\begin{array}{l}\text { Contractor } \\
\text { Related }\end{array}$ & $\begin{array}{l}\text { escalation of } \\
\text { material prices }\end{array}$ & $\begin{array}{l}\text { Natural } \\
\text { Environment }\end{array}$ & $\begin{array}{l}\text { politically } \\
\text { unstable }\end{array}$ & $\begin{array}{l}\text { Authority } \\
\text { related }\end{array}$ \\
\hline 6 & Material related & Operational & $\begin{array}{l}\text { Consultant } \\
\text { Related }\end{array}$ & & External & $\begin{array}{l}\text { Multiple } \\
\text { stakeholder }\end{array}$ & $\begin{array}{l}\text { Technical } \\
\text { issues }\end{array}$ \\
\hline 7 & $\begin{array}{l}\text { Equipment } \\
\text { related }\end{array}$ & $\begin{array}{l}\text { Government } \\
\text { and political }\end{array}$ & Client Related & & Security & $\begin{array}{l}\text { Large: inter- } \\
\text { connected parts, } \\
\text { resources, } \\
\text { contractors }\end{array}$ & \\
\hline 8 & Labor related & Relationship & $\begin{array}{l}\text { External } \\
\text { Related }\end{array}$ & & Management & Equipment & \\
\hline 9 & External & Security/safety & & & Financial & $\begin{array}{l}\text { Infrastructure: } \\
\text { power, water, } \\
\text { housing, seaports } \\
\text { airports, } \\
\text { healthcare }\end{array}$ & \\
\hline 10 & & Legal & & & Resources & & \\
\hline 11 & & & & & Relationship & & \\
\hline
\end{tabular}




\section{$2.3 \quad$ This study}

Unlike approaches that are more common in the literature, this study proposes use of principal components analysis (PCA). PCA works by identifying a few linear combinations of $k$ out of the original $p$ variables that explain most of the variance in the original variancecovariance matrix (of $p$ variables). If found, the $k$ are called the principal components of the original system. Thus, $n$ observations on $p$ variables, may be reduced to $n$ observations on $k$ principal components, which gives the researcher more degrees of freedom. In addition, analysis of principal components often reveals relationships among explanatory variables that were not previously suspected. See for example, Johnson and Wichern (1992).

Geometrically, the k-dimensional linear subspace spanned by the first $\mathrm{k}$ principal components constitutes the best fit to the original data points using the sum of squared perpendicular distances between each of the original data point and the k-dimensional subspace. That is, the principal components are a linear combination of appropriately weighted original variables. The weighting of the observed variables is done such that the resultant $\mathrm{k}$ principal components account for the highest proportion of the original variance (calculated from the $\mathrm{n}$ observations on the original $\mathrm{p}$ variables) that any k-components could account for.

Principal component analysis has not been used much in this literature. One exception however, is McCord et al. (2015) who used this approach to analyze delays within the housing construction sector in Northern Ireland. They concluded that delays can be principally attributed deficiencies in site management, ineffective communication strategies among stakeholders and a lack of coordination between key stakeholders involved in the construction process. They however admit that delay factors can change as a result of regional differentiation.

\subsection{METHODOLOGY}

In this study construction projects are broadly defined to include buildings, bridges, roads, of groundwater construction projects, housing projects, etc. Donor funded development projects are excluded. However, government and private sector funded projects are included.

\subsection{Design of data collection instrument and its administration}

This study started initially with a comprehensive literature search to identify how variables that have been identified as being pertinent to understanding project delays have been grouped (variously called groups, categories, headings, factors, etc.). Examples of such groupings are indicated in Table 1. Careful analysis of the contents of these groupings suggested to this author that the groupings can be rationalized to a total of 12 , which this study refers to as major variables.

A data collection instrument asking respondents to rank these 12 major variables was prepared and discussed with four knowledgeable persons in the construction industry in Ghana. The four are, the Registrar of Architects' Registration Council (which regulates and licenses architects), a construction structural engineer, an architect and a construction manager. Their input helped refine groupings of the initial list of variables and to revise the draft list of 12 major variables to 13 major variables that impact construction delays in Ghana. The 13 major variables are discussed in section 3.2.

The data collection instrument was then administered to stakeholders in the industry. These included randomly selected architects, surveyors, construction site engineers, contractors, owners 
of projects, project management academics, and project management graduate students. Respondents were asked to state (in their opinion) the importance of each of the 13 major variables in influencing project delays on a scale that ranges from 1, 2, 3 through 4 . Thus, this is an even numbered scale. 1 means that, to the respondent, matters related to this factor have minimal impact on project delay, while 4 means matters related to this major variable have huge impact on project delay.

Some researchers use odd numbered scales, (e.g., 1 through 5). However, it is argued in the literature that design of odd numbered scales is such that the middle score ( 3 on a 1 to 5 scale) typically represents a neutral score in the sense that to its left (score 1 or 2) would suggest low impact, while numbers to its right ( 4 and 5) would suggest high impact. A respondent not wanting to commit one way or the other (low or high impact) may just tick the middle score (3). Whereas, in the case of an even numbered scale, ( 1 through 4 for example), the respondent is forced to think through the options and to commit himself/herself one way (low impact) or the other (high impact), no middle or neutral choice. This author prefers the even number approach.

\subsection{Major variables hypothesized to affect delivery of construction projects}

1. VAR1: PROJECT PREPARATION: Client failing to plan on time; planning and scheduling deficiencies; deficiencies in cost estimates; lack of proper scoping; obtaining drawing and other approvals; design changes; delays in furnishing and delivering the site to the contractor.

2. VAR2: CASH FLOW/FINANCE ISSUES: Refers to delay in payment to contractor/supplier; inadequate funds from sponsor/client; Cash flow during construction; Monthly payment difficulties; Financial markets not well developed.

and specifications.

3. VAR3: CONSTRUCTION MATERIALS ISSUES: Refers to shortage of material; takes time to mobilize funds, place orders, clear goods at the ports; poor quality of materials; escalation of material prices; poor procurement practices; changes in material types.

4. VAR4: STATE OF INDUSTRY: Many contractors are not professionals but business people; not keen to invest in developing their own construction business; inadequate qualification of contractor's technical staff; unavailability of advanced design software; not enough professionals. 5. VAR5: INFRASTRUCTURE AVAILABILITY: Unavailability of utilities at site - roads, water, electricity, airports, seaports, etc.

6. VAR6: EQUIPMENT RELATED: Insufficient numbers of equipment; frequent equipment breakdown; Shortage of equipment parts; improper equipment; slow mobilization of equipment.

7. VAR7: CONSTRUCTION METHODS: Inappropriate construction methods; out of date technology; low productivity and efficiency of equipment; lack of high-technology mechanical equipment; mistakes during construction

8. VAR8: CHANGES IN GOVERNMENT REGULATIONS, LAWS AND PRIORITIES: Change in government policy; commitment of government to project.

9. VAR9: CONSULTANT RELATED: Poor communication/coordination between consultant and other parties; lateness in reviewing and approving design documents; conflicts between consultant and design engineer; unclear and inadequate details in drawings.

10. VAR10: LEGAL: lack of clear understanding of contract by stakeholders; absence of punitive delay clauses in contracts; insufficient details in contract documents; contract flaws.

11. VAR11: FORCE MAJEURE: bad weather conditions/rain; other natural occurrence. 
12. VAR12: WORK SITE CONTROLS: accidents and injuries; theft on site; vandalism; inadequate safety and security; site condition; ground conditions and contaminants.

13. VAR13: LABOUR RELATED ISSUES: Shortage of certain skills; poor motivation, morale, absenteeism, quality of equipment.

\subsection{Data analysis}

Data collected were subjected to principal components analysis (PCA). PCA involves eigenvalue decomposition (spectral decomposition) of a matrix into a canonical state. Components are derived from the variance-covariance matrix (or correlation matrix) of the original variables. PCA maximizes the variance of the original variables that is explained by a reduced number of variables. Principal component analysis is undertaken in a sequence of steps. Step 1: Extraction of the Components

The first principal component extracted is one that accounts for the highest amount of total variance among observed variables. It should be correlated with at least some of the observed variables. The second principal component extracted accounts for the highest amount of variance among observed variables that was not accounted for by the first principal component (i.e. correlated with some of the observed variables that were not strongly correlated with the first component) and uncorrelated with the first principal component. The second principal component accounts for less variance than the first. The remaining principal components that are extracted must display the same two characteristics.

\section{Step 2: Determining the number of components to Retain}

Determining the number of components to Retain In principle, PCA results in as many components as there are original variables, $p$. The criteria for extracting $k$ components that account for most of the variances are many. They include:

- Kaiser's (1960) criterion, which suggests settling on $k$ with eigenvalues greater than one as acceptable components under certain conditions;

- Cattell's (1966) scree test. Eigenvalues are plotted against their respective components (horizontal axis) and a line graph is drawn. One then eyeballs the graph for a 'break'. Components to the left of this 'break', with higher eigenvalues are accepted, while those to the right with lower eigenvalues are dropped;

- The proportion of total variance that a factor accounts for determines if the factor is considered important in explaining the variance to be accepted. Acceptable proportions are subjectively determined. Some researchers use $10 \%$;

- Correlation between observed variables and components. High correlation values (positive or negative) are good candidates for retention. Correlation coefficients with magnitudes less than 0.4 are generally discarded, (Stevens, 1986).

A number of computer software, such as Statistical Analysis System and Statistical

Package for the Social Sciences have in-built procedures for extracting important factors.

\subsection{RESULTS}

The questionnaire developed was emailed to 135 respondents. Respondents were randomly selected from active members in good standing with their respective professional 
bodies, namely, architects, engineers, surveyors, contractors and construction site managers. Owners of recently completed projects were also sampled. So were project management and project finance academics, as well as project management graduate students. Useable responses from 68 respondents were returned. The distribution of returned questionnaire is as follows: architects/consultants (10), engineers (10), surveyors (5), contractors (15) and construction site managers (5), owners of recently completed projects (5) were also sampled. So were project management academics (5), as well as project management graduate students (18). Principal components analysis was conducted using Statistical Package for the Social Sciences (SPSS). Many options were specified to allow for the output to be analysed along many dimensions.

\subsection{Summary Statistics}

The maximum score awarded to each of the 13 factors by respondents was 4 . The minimum score awarded to all factors but the Financial issues factor was 1 . The minimum for the variable Financial issues is 2 . The variable with the highest mean is Project preparation (3.6), followed by Financing issues (3.4). The variable with the least mean is Force majeure (1.7). The variable with the least standard deviation is Financial issues. The figure is 0.64 followed by 0.70 for Project preparation. The factor with the highest standard deviation is Force Majeure, 0.99, followed by Legal, 0.97 .

The pair of variables with the highest correlation coefficient are the State of the industry and Infrastructure availability (0.47), followed by State of the industry and Equipment related issues, 0.45. Some correlation coefficients are small. The correlations between Consultant related factor and the other variables and between Force Majeure and other variables are mostly very small (magnitude less than 0.1 ).

\subsection{Principal components}

The overall Kaiser-Meyer-Olkin measure of sampling adequacy was 0.64 , while the pvalue of the Bartlett's test for sphericity was 0 . Thus, outputs of the principal components analysis are deemed adequate. The eigenvalues of the extracted principal components range from 3.33 to 0.24 . Please refer to Table 2. All are significantly different from zero. The first five eigenvalues exceed 1.00 .

The SPSS output also gives communalities after extraction (amount of variance in each variable that is explained by retained components). The Kaiser's criterion of retaining components with eigenvalues of at least one, requires that the number of original variables be less than 30 , and that the average communality be at least 0.70 . This study involves 13 variables and the commonality of six of the variables are between 0.70 and 0.80 . The average of all communalities is 0.66 , close to what Kaiser requires.

Next, we considered the proportions of eigenvalues. The first eigenvalue explains $25.6 \%$ of total (unrotated) variance; the second explains 13.3\%; the fifth explains $8.3 \%$. The last explains only $1.8 \%$. The first five eigenvalues explain $66.4 \%$ of the variance in the original variables. The scree plot suggests a break between the first eigenvalue and the others; and another break between the fifth and the remaining eigenvalues. Putting all these observations together, we settle for five components. 
Table 2: Eigenvalues of extracted components

\begin{tabular}{|c|r|r|c|c|}
\hline Component & Eigenvalue & Difference $^{\mathbf{a}}$ & Proportion \% $^{\mathbf{b}}$ & Cumulative \% $^{\mathbf{c}}$ \\
\hline 1 & 3.329 & 1.5977 & 25.6 & $\mathbf{2 5 . 6 0}$ \\
2 & 1.723 & 0.3768 & 13.31 & $\mathbf{3 8 . 9 0}$ \\
3 & 1.351 & 0.2030 & 10.41 & $\mathbf{4 9 . 3 1}$ \\
4 & 1.148 & 0.0738 & 8.85 & $\mathbf{5 8 . 1 6}$ \\
5 & 1.075 & 0.2952 & 8.28 & $\mathbf{6 6 . 4 4}$ \\
6 & 0.784 & 0.0717 & 6.01 & 72.45 \\
7 & 0.719 & 0.0244 & 5.46 & 77.91 \\
8 & 0.681 & 0.0765 & 5.27 & 83.18 \\
9 & 0.611 & 0.0308 & 4.68 & 87.86 \\
10 & 0.578 & 0.1161 & 4.44 & 92.30 \\
11 & 0.459 & 0.1586 & 3.55 & 95.85 \\
12 & 0.306 & 0.0668 & 2.33 & 98.18 \\
13 & 0.238 & & 1.82 & 100.00 \\
SUM & $\mathbf{1 3 . 0 0 0 0}$ & & & \\
\hline
\end{tabular}

Legend: ${ }^{\mathrm{a}}$ Differences between successive eigenvalues; ${ }^{\mathrm{b}}$ eigenvalue as proportion of the sum of eigenvalues; ${ }^{\mathrm{c}}$ sum of proportions of eigenvalues (cumulative).

\section{Figure 1: Scree plot of eigenvalues}

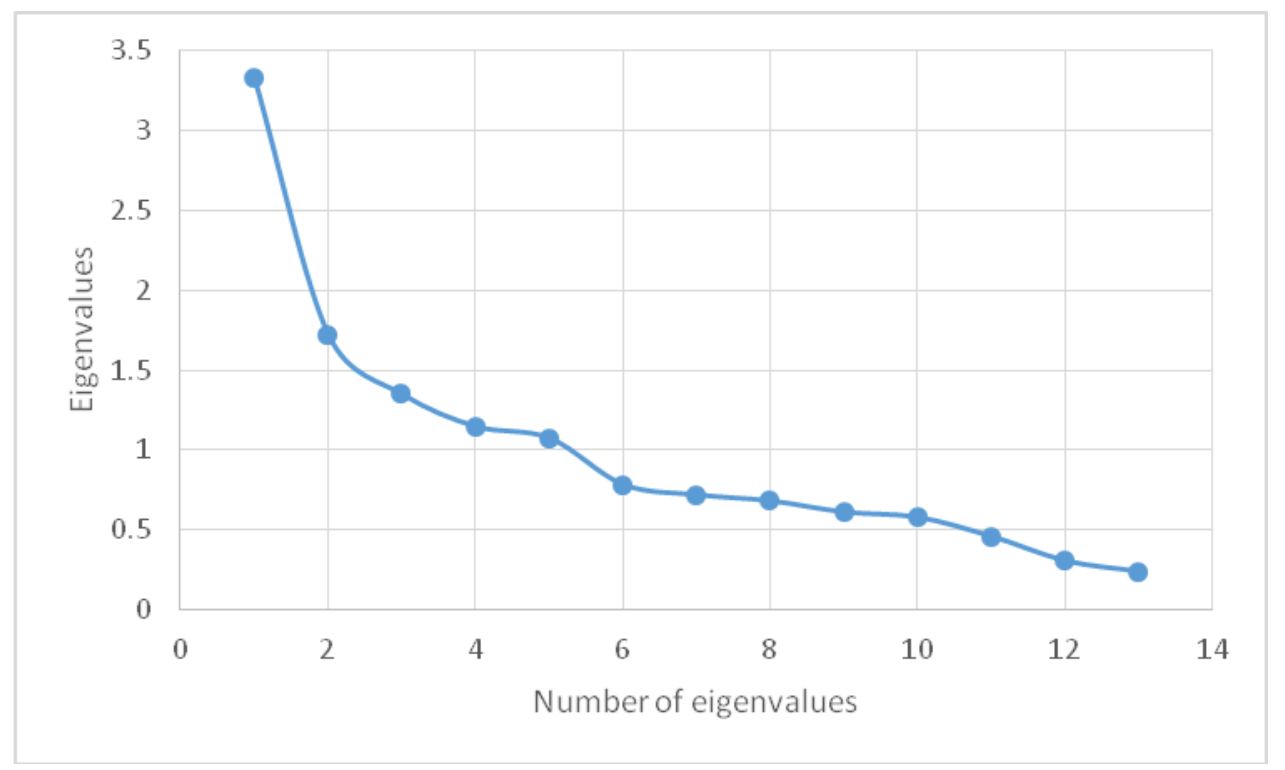

\subsection{Retained Components}

The component matrix indicates the correlation between observed variables (rows) and retained components (columns). The entries of the component matrix are also called factor loadings. Factor loadings with absolute values above 0.4 are reported, Stevens (1986). The 
component matrix was then subjected to the direct Oblimin rotation (transformation) as the absolute values of correlation coefficients between certain components exceeded 0.23 (Field, 2005).

Referring to Table 3, three variables, State of Industry, Infrastructure Availability, and Legal Issues load onto Component 1. Two variables, Consultant Related and Labour Related issues load onto Component 2. Another pair of variables, Project Preparation and Construction Methods load onto Component 3. Change in Government Regulation and Force Majeure load onto Component 4. And Construction Material Issues and Equipment Related issues load onto Component 5.

Table 3: Rotated Component matrix - correlation between variables and components

\begin{tabular}{|c|c|c|c|c|c|}
\hline VARIABLES & PC1 & PC2 & PC3 & PC4 & PC5 \\
\hline Project Preparation & & & 0.802 & & \\
\hline Cash Flow * & 0.429 & & 0.458 & & \\
\hline Construction Material Issues & & & & & -0.793 \\
\hline State of Industry & 0.672 & & & & \\
\hline Infrastructure Availability & 0.845 & & & & \\
\hline Equipment Related & & & & & -0.772 \\
\hline Construction Methods & & & 0.489 & & \\
\hline $\begin{array}{l}\text { Changes in govt regulations, } \\
\text { laws and priorities }\end{array}$ & & & & 0.731 & \\
\hline Consultant Related & & 0.869 & & & \\
\hline Legal & 0.47 & & & & \\
\hline Force Majeure & & & & 0.756 & \\
\hline Work Site Controls* & 0.585 & 0.48 & & & \\
\hline Labour Related Issues & & 0.759 & & & \\
\hline
\end{tabular}

$\mathrm{PC} 1=$ principal component $1, \mathrm{PC} 2=$ principal component 2 , etc.

\subsection{Discussion}

Our results suggest that five principal components account for $66.34 \%$ of the total variance, and that these are important enough to be retained. We argue that State of Industry, Infrastructure Availability, and Legal Issues which load onto Component 1 speak to but the general state of affairs in respect of delivering projects in Ghana. We argue further that, Consultant Related and Labour Related issues which load onto Component 2, speak to the state of human capital in delivering projects in Ghana. Further, Project Preparation and Construction Methods which load onto Component 3 speak to preparations for specific projects and the methods by which these projects are undertaken. In addition, Construction Material Issues and Equipment Related issues which load onto Component 5 address the question of inputs for project delivery in Ghana. Finally, we reason that Change in Government Regulation and Force Majeure, which load onto Component 4, are exogenous to the project delivery industry in Ghana.

Each of Cash Flow and Work Site Controls loaded onto two components with factor loadings above 0.4. Thus, both variables were dropped. It is reasoned that nothing is lost by 
dropping Cash Flow, since performance of all retained variables have cash flow implications. Similarly, as defined, Work Site Controls would appear to have much in common with Labour Related issues, which is retained.

Finally, the descriptions given the five components here are very instructive and intuitive (the general state of affairs in respect of delivering projects; the state of human capital in delivering projects; preparations for specific projects and the methods by which these projects are undertaken; inputs for project deliver; exogenous to the project delivery industry). In addition, they clarify factors that explain project delays and cost overruns.

The five components identified here provide a means of more focused approach to addressing delays and cost overruns versus the eight identified by Addo (2015), six by Doloi (2012), eight by PWC, 10 by Amoatey et al. (2015) and 10 by Chileshe and Yirenkyi-Fianko (2011). Please refer to Table 1.

Of the approaches adopted to reduce the original number of variables, only Doloi attempted the factor analysis approach, one that is as rigorous as the principal components analysis adopted here.

It is noted that, results obtained from this study would have been stronger had the five components retained here explained a higher proportion of total variance in the original 13 variables. This may partly be due to the sample size, which could have been higher than 68 .

\subsection{CONCLUDING REMARKS AND RECOMMENDATIONS}

This study concludes that, the state of the construction industry to deliver projects, the state of human capital, project specific factors, factors relating to project inputs and exogenous factors are major factors that impact project delays and cost overruns in Ghana. As such, it is recommended that these factors should serve as a scientific starting point for efforts aimed at reducing construction delays and cost overruns.

\section{Acknowledgement}

The author is grateful to the University of Ghana Business School for partially funding this study.

And also, to L. Adzobu, R. B. Asare, E. Mekpor, S. E. Nyarko, and R. Boateng for excellent research assistance. 


\section{References}

Addo, J. N. T. (2015). Delay and Its Effect on The Delivery of Construction Projects in Ghana, African Journal of Applied Research, 1(1), 236-246.

Amoatey, C. T., Ameyaw, Y. A., Adaku, E. \& Famiyeh, S. (2015). Analysing delay causes and effects in Ghanaian state housing construction projects, International Journal of Managing Projects in Business, 8(1), 198-214.

Assaf, S. A. \& El-Hejji, S. (2006). Causes of delay in large construction projects, International Journal of Project Management, 24, 349-357.

Cattell, R. B. (1966). The scree test for the number of factors. Multivariate Behavioral Research, 1, 245-276.

Chan, D. W. and Kumaraswamy, M. M. (1997). A comparative study of causes of time overruns in Hong Kong construction projects. International Journal of Project Management, 15(1), 55-63.

Chileshe, N and Yirenkyi-Fianko, A. B. (2011). "Perceptions of threat risk frequency and impact on construction projects in Ghana: opinion survey finding", Journal of Construction in Developing Countries, 16(2), 115-149.

Daily Graphic, (2013). Ghana's seat of government moves back to Flagstaff House, Available at https://dilemma-X.net/2013/02/08/ghanas-seat-of-government-moves-back-to-flagstaffhouse/

Doloi, H. (2009). Analysis of pre-qualification criteria in contractor selection and their impacts on project success, Construction Management and Economics, 27(12), 1245-1263

Doloi, H., Sawhney, A., Iyer, K. C. and Semeer, R. (2012). Analyzing factors affecting delays in Indian construction projects, International Journal of Project Management, 30, 479-489.

Field, S, (2015), Discovering statistics using SPSS (2 ${ }^{\text {nd }}$ Edition), London: Sage.

Frimpong, Y., Oluwoye, J. and Crawford, L, (2003). Causes of delay and cost overruns in construction of groundwater projects in a developing countries; Ghana as a case study, International Journal of Project Management, 21(5), 321-326.

Johnson, R. A., and Wichern, D. W., (1992). Applied multivariate statistical analysis, PrenticeHall, N.J.

Kaiser, H. F. (1960). The application of electronic computers to factor analysis. Educational and Psychological Measurement, 20, 141-151.

Kim, H., Soibelman, L. and Grobler, F. (2008). Factor selection for delay analysis using Knowledge Discovery in Databases, Automation in Construction 17, 550-560.

Mansfield, N. R., Ogwu, O. O. and Doran, T. (1994). Causes of delay and cost overruns in Nigerian construction projects, International Journal of Project Management, 20, 254260.

Marzouk, M. M. and El-Rasas, T. (2014). Analyzing delay causes in Egyptian construction projects, Journal of Advanced Research, 5, 49-55.

McCord, J., McCord, M., Davis, P. T., Haran, M and Rodgers, W. J. (2015). Understanding delays

in housing construction: evidence from Northern Ireland, Journal of Financial Management of Property and Construction, 20(3), 286-319.

Odeh, A. M. and Battaineh, H. T. (2002). Causes of construction delay: traditional contracts, International Journal of Project Management, 20(1), 67-73. 
PriceWaterhouseCoopers, (2014). Capital projects and infrastructure in East Africa, Southern Africa, and West Africa, Available at www.pwc.co.za/infrastructure (Accessed May 2017).

Social Security and National Insurance Trust (SSNIT), (2013). "SSNIT Collaborates with Ministry to Reactivate Abandoned Affordable Housing Project," Daily Graphic, Available at: graphic.com.gh/archive/General-News/ssnit-collaborates-withministry-to-reactivate-abandonedaffordable-housing-project.html

Stevens, J. (1986). Applied multivariate statistics for the social sciences. Hillsdale, NJ: Lawrence Erlbaum Associates. 